\title{
COVID-19 THERAPEUTICAL OPTIONS: OVER- VIEW ON CURRENTLY ANTI-INFLAMMATORY AND ANTICOAGULANT DRUGS USED
}

\author{
Idrys Henrique Leite Guedes ${ }^{1}$ \\ Gregório Dantas dos Santos ${ }^{2}$ \\ Antonio Bonildo Freire Viana ${ }^{3}$ \\ Geldane da Silva Araújo ${ }^{4}$ \\ Tálio Câmara Pinto dos Santos ${ }^{5}$ \\ Cláudia Jassica Gonçalves Moreno ${ }^{6}$ \\ Silvia Tavares Donato ${ }^{7}$
}

\begin{abstract}
Since December of Wuhan, China to worldwide. 2019, an outbreak of viral infection causing respiratory disease With initial symptoms similar to Coronavirus related to Sevewith a new virus, the Coronavire Acute Respiratory Syndrome ridae family, emerged in the city (SARS) and an increase in the
\end{abstract}

1 Universidade Federal de Campina Grande (UFCG), Campina Grande - PB

2 Universidade Federal de Campina Grande (UFCG), Campina Grande - PB

3 Universidade Federal de Campina Grande (UFCG), Campina Grande - PB

$4 \quad$ Universidade Federal de Campina Grande (UFCG), Campina Grande - PB

5 Universidade Federal de Campina Grande (UFCG), Campina Grande - PB

6 Universidade Federal do Rio Grande do Norte (UFRN), Natal $\mathrm{RN}$

7 Universidade Federal de Campina Grande (UFCG), Campina Grande - PB

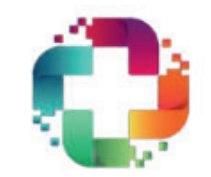


ISSN: 2763-5724

Vol. 01 - n 04 - ano 2021

Editora Acadêmica Periodicojs

speed of spread the World Health Organization (WHO) decrees a pandemic situation on March 11, 2020. Moreover, approximately 3.4 million deaths worldwide and 165 million cases were confirmed. Thus, contributing to an important global health problem responsible for changes in economic and social paradigms. There is no available treatment for COVID-19 until today. Although, several drugs are being used as alternative therapeutics against the diseases, mainly in severe cases. This review aimed to highlight the current anti-inflammatory and anticoagulant alternatives treatment measures for control of COVID 19 infection. Here we discuss the drugs, pharmacological proprieties, and the respective studies COVID-19 related, and also, several research protocols to respond and control the pandemic for the prophylaxis and treatment.

Keywords: COVID-19; Therapeutic Approaches; Drug Therapy

\section{Background}

In December 2019, an outbreak of viral infection causing respiratory disease with a new species of the virus, the Coronaviridae family, emerged in the city of Wuhan, China. With initial symptoms similar to Coronavirus related to Severe Acute Respiratory Syndrome (SARS), the World Health Organization (WHO) established the 2019$\mathrm{nCoV}$ nomenclature for the new virus and then was renamed as SARS-CoV-2 by the International Committee on Virus Taxonomy (PAHO, 2020; WORLD HEALTH ORGANIZATION, 2020b).

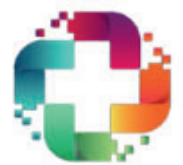


Vol. 01 - n 04 - ano 2021

Editora Acadêmica Periodicojs

The virus spread rapidly to China and then to other Asian countries, the Middle East, the Africa continent, the Americas, and Europe. With an increase in the speed of spread, on March 11, 2020, the World Health Organization (WHO) decrees a pandemic situation. Since then, the world has been alarmed by the exponential and rapid increase, of viral infection that affects the respiratory system, resulting in SARS. The updated COVID-19 case numbers are available on the Johns Hopkins University platform (UNIVERSITY, 2021). Moreover, approximately 3.4 million deaths worldwide of 165 million confirmed cases. Thus, contributing to an important global health problem responsible for changes in economic and social paradigms (BEZERRA, 2010; PAHO, 2020).

Although most people with COVID-19 develop mild $(40 \%)$ or moderate $(40 \%)$ disease. Approximately 15\% develop severe disease requiring oxygen support and 5\% have a critical disease with complications such as respiratory failure, acute respiratory distress syndrome, sepsis and septic shock, thromboembolism and/or multiple organ failure, including acute kidney injury and cardiac injury (SIDDIQI; MEHRA, 2020; WORLD HEALTH ORGANIZATION, 2020b).

Clinical diagnosis is characterized initially as flu syndrome and may the patient present fever and/or respiratory symptoms must be made through clinical-epidemiological investigation, anamnesis, and appropriate physical examination. Also, patient recent history of close or home contact (last 14 days) before the appearance 
ISSN: 2763-5724

Vol. 01 - n 04 - ano 2021

Editora Acadêmica Periodicojs

of signs and symptoms with individuals already confirmed for COVID-19. The recommended evaluation should occur according to the pneumonia severity rates and sepsis guidelines (when suspected) in all patients with severe disease(MINISTÉRIO DA SAÚDE, 2020a, 2020b).

Information about this new coronavirus is still limited to characterize the clinical disease spectrum, as many pieces of evidence are based on early analysis of cases of previous coronavirus infections, such as Severe Acute Respiratory Syndrome (SARS) and Middle East Respiratory Syndrome (MERS). Thus, it is ratified that the clinical characteristics are not specific and can be similar to those caused by respiratory viruses, and it is recommended to consult the periodical updates disclosed by official health institutions, such as the Mi- nistry of Health, the Brazilian

Health Agency.

Considering the situation of emergency coping and the lack of consistent and specific scientific studies for the prophylaxis and treatment of COVID-19, WHO has developed several research protocols, which use a combination of molecular and serological tests, gathered in epidemiological parameters, in an attempt to respond and control the pandemic caused by COVID-19. Supporting a global initiative, which aims to allow any country to have its decision-making to implement or suspend appropriate social and public health measures for the prevention and control of virus infection. More clinical tests need to be carried out to guarantee the use and effectiveness of the drugs used and reviewed in the treatment and prevention of COVID-19, while

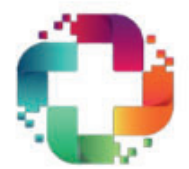


ISSN: 2763-5724

Vol. 01 - n 04 - ano 2021

Editora Acadêmica Periodicojs

the protocols are being applied

in the desire for a practical and

The compound is a syn-

effective therapeutic approach

(TRINDADE et al., 2020).

Given the pandemic declaration by the World Health Organization and the initiatives of the Ministry of Health to face this situation in Brazil, the use of this work aims to compile and discuss the data published so far, as well as to verify the benefits and harms of drugs that are being use for the treatment of COVID-19, taking into account the great diversity of protocols that are in force at the moment.

Literature Review:

nerived, presented significant application as antiemetic, antineoplastic, adrenergic, Anti-Inflammatories - DEXA- immunosuppressive, xenobiotic METASON and anti-inflammatory (NATIONAL CENTER FOR BIOTE-

CHEMICAL STRUCTURE, CHNOLOGY INFORMATION, PHARMACOLOGY AND 2020b).

CLINICAL INDICATION

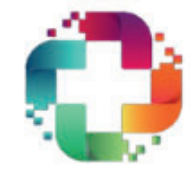


ISSN: 2763-5724

Vol. 01 - n 04 - ano 2021

Editora Acadêmica Periodicojs

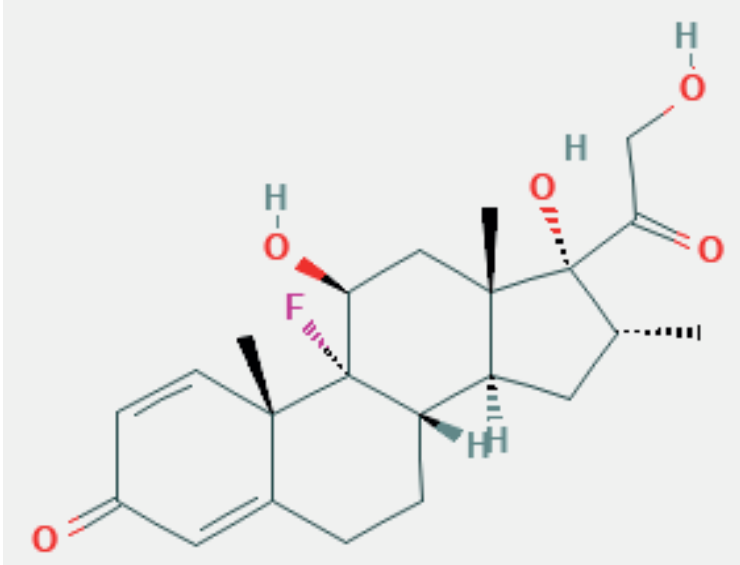

Figure 1. Chemical structure of Dexamethasone.

Dexamethasone is nisms of action similar to those a synthetic steroidal anti-in- of its endogenous representative flammatory drug that generates, cortisol (SPOORENBERG et al., besides general effects such as 2014).

the reduction of inflammatory Pharmacokinetically, and immunological responses, dexamethasone is rapidly absorseveral alterations in the orga- bed in the gastrointestinal tract, nism, including the metabolism has a rapid onset of action and of macronutrients. Belongs to po- maximum effect range, and its tential drug highest class and can distribution occurs mainly throube replaced by a dose 26.6 times gh binding to plasma proteins in higher of hydrocortisone and 5.3 about $65 \%$ to $90 \%$. The drug actimes higher of methylpredni- tion is longer, about 2 to 3 days, solone, participating in mecha- with a plasmatic half-life of 3 to

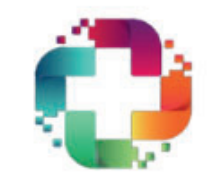


Vol. 01 - n 04 - ano 2021

Editora Acadêmica Periodicojs

4.5 hours, and a tissue 36 to 54 hours. The metabolization of dexamethasone is primarily hepatic and renal excretion, through inactive metabolites (SPOORENBERG et al., 2014).

The clinical indication occurs mainly for allergopathies, rheumatic diseases, dematopathies, ophthalmopathies, endocrinopathies, pneumopathies, hemopathies, neoplastic diseases, edematous states, cerebral edema, and gastrointestinal diseases. The drug has capacity to reduce the production of cytokines and actions in such infectious conditions. However, the inflammatory reaction provoked by these pathologies is generally mitigated, with suppression of the white cells as a whole, which makes the continuous use of glucocorticoids dangerous (SPOORENBERG et al., 2014).

\section{MECHANISM OF ACTION \\ AND SPECTRUM OF ACTI- VITY IN COVID-19}

Given the pandemic incidence of COVID-19, corticosteroids, responsible for immunosuppression - inhibiting $\mathrm{T}$ cells and preventing the production of immunoglobulins by B cells- and even increasing the replication period in the blood of the coronavirus causing MERS, have been contraindicated by agencies such as the Centers for Disease Control and Prevention of the U.S. Department of Health and $\mathrm{Hu}-$ man Services. Yet, SARS-Cov19, the amount of virus in the blood is lower even in patients who develop severe disease, because of that the administration of steroidal anti-inflammatory drugs can reduce the damage caused by cytokines. During a short period of time, may avoid the reduction of

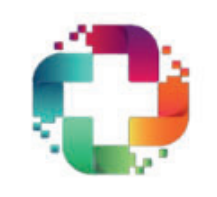

HEALTH \& SOCIETY 
ISSN: $2763-5724$

Vol. 01 - n 04 - ano 2021

Editora Acadêmica Periodicojs

production of $\mathrm{T}$ lymphocytes and antibodies. Besides, studies revealed as a possible benefit of this class of drugs against COVID-19 (PATEL et al., 2020; THEOHARIDES; CONTI, [s. d.]).

In this sense, the benefit of positive modulation of anti-inflammatory cytokines and negatively of pro-inflammatory cytokines is expressive, characteristics that reduce the cytokine storm commonly described as one of the main problems triggered by the pathology that causes high demand for mechanical respirators (JOHNSON; VINETZ, 2020).

TOXICITY AND ADVERSE REACTIONS

The drug-drug interactions of dexamethasone occur with the following drugs: acetylsalicylic acid, phenytoin, pheno- barbital, ephedrine and rifampicin's, indomethacin, coumarin anticoagulants and potassium spoliating diuretics. Its main adverse reactions are: posterior subcapsular cataract, glaucoma with possible lesion of the optic nerves and secondary ocular infections due to fungi or viruses (SPOORENBERG et al., 2014).

\section{RECOMMENDATIONS ON THE TREATMENT OF CO- VID-19}

In clinical and hospital practice, usually the initial dose varies from 0.75 to $15 \mathrm{mg}$ per day and the dosage should be progressively reduced or the administration gradually stopped. During prolonged treatment it is mandatory to proceed at regular intervals and with follow-up through routine clinical exams, such as determination of serum 
ISSN: 2763-5724

Vol. 01 - n 04 - ano 2021

Editora Acadêmica Periodicojs

potassium, urine test, blood glucose two hours after a meal, determination of blood pressure and body weight, and chest X-ray (SPOORENBERG et al., 2014).

There are no systematic review studies, the main form of scientific dissemination on which public policies are outlined, which recommend specific dosage for treatment of COVID-19. Although, the administration of $6 \mathrm{mg}$ daily for up to 10 days, for treatment of SARS-CoV-2, in a study published in The New England Journal of Medicine on July 17 by the collaborative group RECOVERY, was positive. Patients who received oxygen with or without invasive mechanical ventilation by reducing mortality by $8-26 \%$ at 28 days after randomization of patients. In addition, similar results were obtained in recent study on the subject, published in the Journal of the American Medical Association (JAMA) by the collaborative group REACT, revealing potential benefit of the use of the drug in the group of patients with critical condition of the disease. Thus, WHO was recommended the use of corticosteroids in such cases of infection by SARS-CoV-2 (DEXAMETHASONE IN HOSPITALIZED PATIENTS WITH COVID-19, 2021; LESTER; SAHIN; PASYAR, 2020; STERNE et al., 2020).

\section{IBUPROFEN}

CHEMICAL STRUCTURE, PHARMACOLOGY AND CLINICAL INDICATION

Derived from propanoic acid, ibuprofen is an organic substance that presents the functions carboxylic acid restricted to a small part of the molecule and

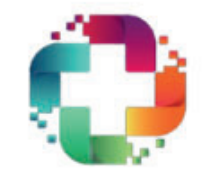


ISSN: $2763-5724$

Vol. 01 - n 04 - ano 2021

Editora Acadêmica Periodicojs

hydrocarbon in the rest being (fi- binding (NATIONAL CENTER

gure 8). Therefore, highly inso- FOR BIOTECHNOLOGY IN-

luble and, consequently, presen- FORMATION, 2020a).

ting high absorption and protein

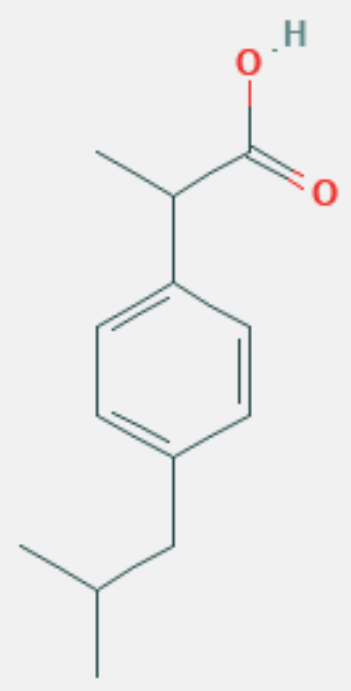

Figure 2. Chemical structure of Ibuprofen.

As non-steroidal anti- ticular rheumatic problems, pain -inflammatory drug (NSAID) associated with inflammatory and prostaglandin synthesis inhi- and/or traumatic processes and bitor, ibuprofen has analgesic and pain associated with colds and flu antipyretic properties. Clinical (BUSHRA; ASLAM, 2010).

use to reducing fever and tem- $\quad$ NSAIDs present good porary improvement of mild and oral absorption, with approximamoderate pain, such as headache, tely $80 \%$ of the absorbed dose in toothache, muscle pain, pain re- the gastrointestinal tract, provilated to non-articular and periar- ding fast onset of action - about 
Vol. 01 - n 04 - ano 2021

Editora Acadêmica Periodicojs

30 minutes after administration. ibuprofen is presumed to be able

The protein binding rate is almost total $(99 \%)$, the maximum plasma concentration occurs between 1 to 2 hours. The elimination half-life is 1.8 to 2 hours and the action during 4 to 6 hours. The metabolization is hepatic and the elimination occurs around 24 hours with inactive metabolites (BUSHRA; ASLAM, 2010).

\section{MECHANISM OF ACTION} AND SPECTRUM OF ACTIVITY IN COVID-19

Its mechanism of action occurs mainly through the inhibition of the transcription factor kappa B (NF-kB) and other inflammatory mediators, such as interleukin-6 (IL-6), elements that are stimulated in the infection by COVID-19, representing potential benefit for the organism infected by the virus. In addition, to prevent COVID-19 entering the cells by activating the cleavage of the converting enzyme angiotensin 2 (ACE2) by the ADAM-17 proteins present in the cell membrane (MICALLEF; SOEIRO; JONVILLE-BÉRA, 2020; ROBB et al., 2020; SMART et al., 2020).

\section{TOXICITY AND ADVERSE}

\section{REACTIONS}

Ibuprofen is contraindicated in allergic patients and those where the adverse effects can be added to existing pathologies, such as: severe heart, liver or kidney failure; ulcerative colitis; Crohn's disease; history of peptic ulcers, bleeding or gastrointestinal perforation. Similarly, individuals with asthma, urticaria or allergic reactions after the administration of acetylsalicylic 
ISSN: 2763-5724

Vol. 01 - n 04 - ano 2021

Editora Acadêmica Periodicojs

acid, not even pregnant women, especially in the 3rd trimester of pregnancy, should not use the drug (BUSHRA; ASLAM, 2010).

RECOMMENDATIONS ON THE TREATMENT OF COVID-19

Amongst the first months of the SARS-CoV-2 pandemic, ibuprofen was contraindicated by the WHO to treat patients affected by the syndrome. This fact was resulted from studies published at the time, which pointed the drug as an obstacle to the host-defense response to be undertaken by the body against COVID-19. And Both of stage, the incubation stages and mild stages of the disease, and an immunological reaction could worsen the pathology. However, later published studies have shown not only the safety of this use but also its capacity to reduce mortality from the pathogenesis. Besides, the alert of need for further studies to ensure expressive clinical conclusions, the recommendations is to use normally (MICALLEF; SOEIRO; JONVILLE-BÉRA, 2020; ROBB et al., 2020; SMART et al., 2020). Consecutively, the indicated dose of ibuprofen for the treatment of Sars-Cov-2 is not clarify, even though it is not mentioned in the articles that evaluate the benefit or harm to treat the disease, the dose administered in patients participating in the studies (MICALLEF; SOEIRO; JONVILLE-BÉRA, 2020; ROBB et al., 2020; SMART et al., 2020).

ANTICOAGULANTS - HEPARIN

CHEMICAL STRUCTURE, PHARMACOLOGY AND 
Vol. 01 - n 04 - ano 2021

Editora Acadêmica Periodicojs

CLINICAL INDICATION

Heparin, showed in figure 9, is an anticoagulant and antithrombotic agent discovered in 1916 at John Hopkins University. The effects on the organism laid the foundations of current knowledge regarding hemostasis and thrombosis. In addition, this knowledge has supported the development of fractionated derivatives of heparin (in this group are the low molecular weight heparins [HBPM - figure 10]) and several groups of anticoagulant drugs subsequently (for example, direct oral anticoagulants).

The chemical structure, described as a natural sulfated glycosaminoglycan with high anionic charges. Classified as a linear polysaccharide, it consists of 4 linked units of 2-hyduronic acid 2- sulfate ( $\alpha$-IdA-2S) and $\alpha$-D-glucosamine N, 6-disulfated
( $\alpha-\mathrm{GlcN}-\mathrm{N}, 6 \mathrm{diS})$. Other units less common, can be found in this biomolecule, depending on the animal tissue (J; P; W, 2018; TOVAR et al., 2016).

Heparin is the second mostly biological product use in therapies worldwide, behind only insulin, and produced from animal tissues - dog liver, bovine lung, porcine intestine and bovine intestine. Currently, porcine and bovine intestines are the main raw materials of heparin produced worldwide [69]. The heparin exercises its anticoagulant action through the interaction with factors and inhibitors of coagulation. The main inhibitor of plasma coagulation is the antithrombin, which targets activated coagulation factors, such as FXIIa, FXIa, FXa, FIXa, FVIIa and FIIa. Since these activated clotting factors are serine proteases, the antithrombin is classi-

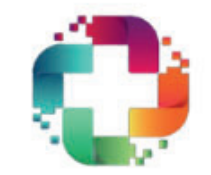


ISSN: 2763-5724

Vol. 01 - n 04 - ano 2021

Editora Acadêmica Periodicojs

fied as a serine protease inhibitor (serpine). The heparin, acting as a catalyst, exerts its anticoagulant action through the potentiation of the inhibitory activity of the antithrombin and other serpins (MULLOY et al., 2016).

The non-fractionated heparins, in the form of heparin sodium, are indicated in Brazil for the prevention of thrombi in the hemodialysis circuit, as well as in the prevention of thromboembolic phenomena in patients with renal insufficiency in hemodialysis program. Low molecular weight heparins, represented by enoxaparin sodium, are indicated in the treatment of deep venous thrombosis - with or without pulmonary embolism - of unstable angina and myocardial infarction without ST-segment elevation (it is administered concomitantly to acetylsalicylic acid). Sodium enoxaparin is also indicated for prophylaxis of venous thromboembolism in surgical contexts and prolonged restriction of mobilization (bedridden patients). In addition, like heparin sodium, it can be used in the prevention of thrombus formation in the hemodialysis circuit. Heparins (heparin sodium and enoxaparin sodium) are contraindicated in situations of hypersensitivity to the substance and its derivatives, thrombocytopenia and active hemorrhages with high risk. Heparin sodium is also contraindicated in full dose when coagulation tests are not available at appropriate intervals, in vascular disorders, in severe liver and kidney failure, as well as in the presence of malignant tumors with high capillary permeability of the digestive tract. The risk in pregnancy is classified as grade $\mathrm{C}$ and should always be used with medical supervision and guidan-

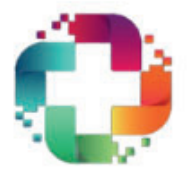


Vol. 01 - n 04 - ano 2021

Editora Acadêmica Periodicojs

ce. Pregnant women, infants and newborns should not use the presentation of heparin containing benzyl alcohol. In substitution, the use of heparin free of preservatives is recommended. The administration of these drugs should be done intravenously or subcutaneously, and the intramuscular route is not recommended (ANVISA, 2007).

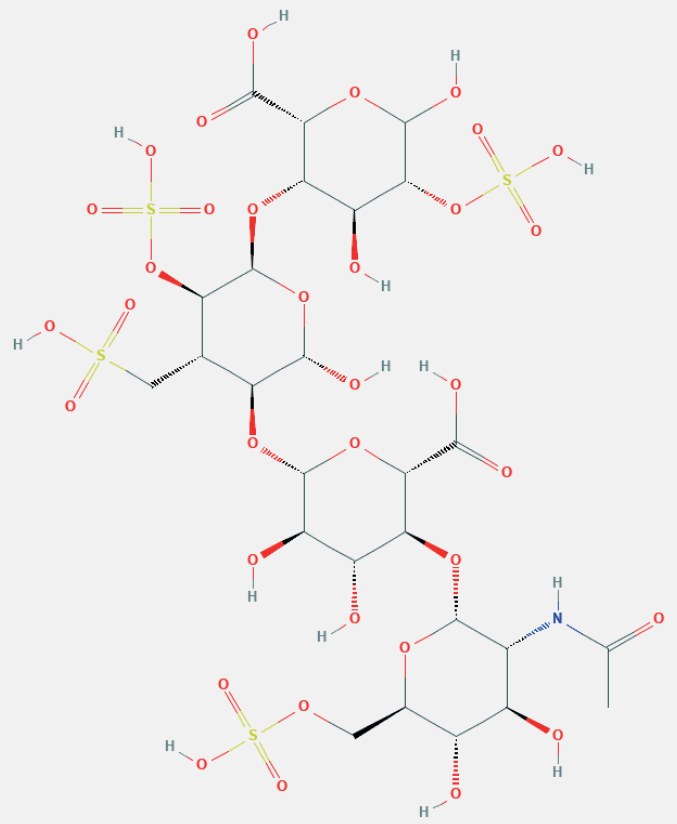

Figure 3. Chemical structure of unfractionated Heparin.
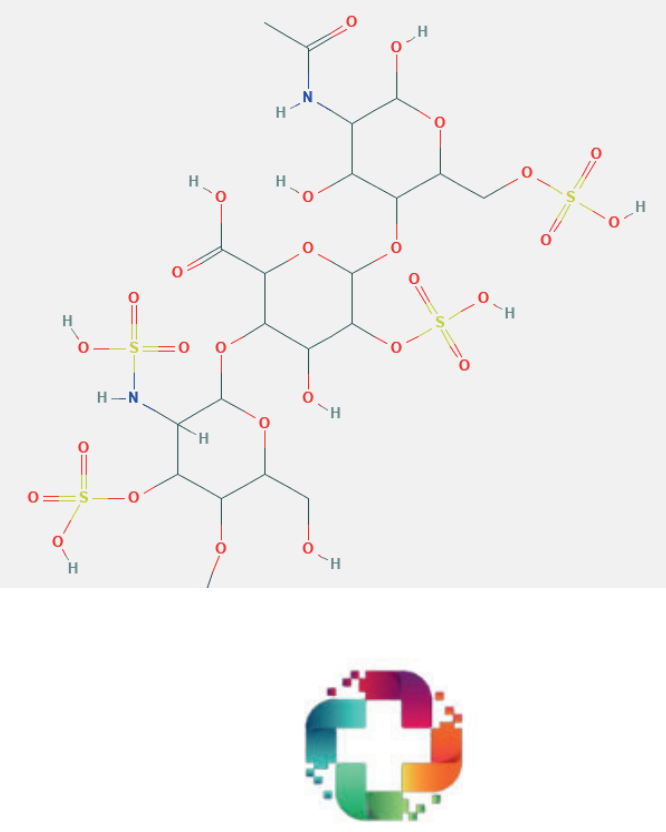
ISSN: $2763-5724$

Vol. 01 - n 04 - ano 2021

Editora Acadêmica Periodicojs

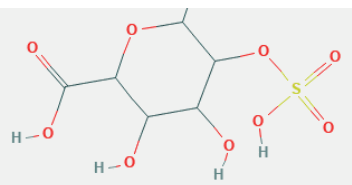

Figure 4. Chemical structure of low molecular weight Heparin.

MECHANISM OF ACTION to treat ICD from its indirect an-

AND SPECTRUM OF ACTI- tithrombinic action and its rapid

VITY IN COVID-19

anticoagulant effect, preventing

the thrombus from spreading.

Patients affected by CO- These effects occur from the me-

VID-19 often have disseminated chanism of common action of he-

intravascular coagulation (DIC) parin by binding to antithrombin

when in a severe state. This is III and inactivating coagulation

due to the intense use of hormo- factors IXa, XIa, XIIa and, espe-

nes for the treatment of the dise- cially, thrombin, preventing the

ase, especially corticosteroids, action of these proteins in the in-

allied to the long stay in dorsal trinsic and extrinsic pathways of

or ventral decubitus position, the the coagulation cascade (TANG

induction of coagulopathies ge- et al., 2020; THACHIL, 2020).

nerated by sepsis and hypoxia, In addition, it was pro-

which increases the factor indu- posed in September another me-

ced by hypoxia and blood visco- chanism of action by which it is

sity. In this sense, heparin - both possible to benefit from the use of

low molecular weight and non- heparin. It is the facilitation of in-

-fractionated - is shown to be an fection of the cells from heparan

important therapeutic tool used sulfate, a polysaccharide present

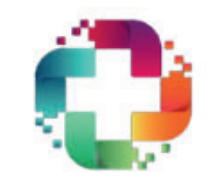

HEALTH \& SOCIETY 
Vol. 01 - n 04 - ano 2021

Editora Acadêmica Periodicojs

in the cell membrane that favors

the open conformation of the bin-

Heparin anticoagulant

ding domain to the angiotensin 2 therapies should be administeconverting enzyme (ACE 2) rered with caution due to the hiceptor present in Sars-Cov-2 and, ghest risk of bleeding, hemostaconsequently, the binding of such sis changes, peptic ulcers, recent viral spicules to the angiotensin ischemic stroke, uncontrolled se2 converting enzyme -protein to vere arterial hypertension, diabewhich the Sars-Cov-2 binding tic retinopathy, neurosurgery or has been extensively studied since the beginning of the pandemic recent ophthalmic surgery, and in concomitant use with other drugs as a potential cause for lung dathat affect hemostasis. Wole dose mage. The non-fractionated exogenous heparin was listed by this study, based on simulations, as a therapeutic focus and, therefore, on further studies, stimulating the closed conformation of such domains, revealing probable benefit of use in patients with non-serious conditions (CLAUSEN et al., 2020). treatments can cause hemorrhages any organ and associated with mortality risk. Reports of adrenal, ovarian and retroperitoneal hemorrhage have already been described in the context of heparinization and gum bleeding symptom in overdose case. Abrupt falls in hematocrit or blood pressure are indications that raise suspicion for a bleeding

TOXICITY AND ADVERSE REACTIONS event (ANVISA, 2007).

Elderly patients, heparin

low-dose is recommended under 
ISSN: 2763-5724

Vol. 01 - n 04 - ano 2021

Editora Acadêmica Periodicojs

observation. Howsoever, no bleeding has been observed in the context of prophylactic doses, but careful clinical monitoring, especially in patients aged 80 years due to the risk of bleeding complications.

Also, heparinized patients may present the so-called "White Thrombus Syndrome". In this case, heparin induces irreversible platelet aggregation of thrombocytopenic. Heparinized patients should also not be submitted to epidural anesthesia or spinal puncture due to the risk of spinal hematoma and paralysis.

Abdominal hemorrhages were reported in two patients with atrial fibrillation and SARS-CoV-2 infection (ÁLVAREZ-RODRÍGUEZ, 2020). Additionally, a case of prophylactically heparinized COVID-19 patient with heparin-induced thrombocytopenia also was re- ported (LINGAMANENI et al., 2020). Besides, thromboembolic events in severe SARS-CoV-2 infected patients notice in undergoing cardiopulmonary bypass and prophylactic heparinization (PARZY et al., 2020). These cases recall the importance of assessing comorbidities during the decision of prophylactic or therapeutic anticoagulation and continuous monitoring in patients with complications. On the other hand, it exposes the gaps still present in the management of COVID-19.

\section{RECOMMENDATIONS ON THE TREATMENT OF CO- VID-19}

The use of heparin has been associated with lower mortality in patients with greater scores (four) on the scale created by the International Society

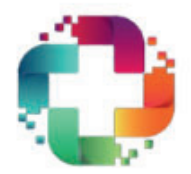


Vol. 01 - n 04 - ano 2021

Editora Acadêmica Periodicojs

of Thrombosis and Homeostasis for sepsis-induced coagulopathies, as well as for those with dimers-d higher than $3.0 \mu \mathrm{g} / \mathrm{mL}$ (mortality $20 \%$ lower), for those with lower scores or low dimers-d levels there was no significant difference. For individuals with adult respiratory distress syndrome (ARDS), the reduction in mortality is even greater (about $48 \%$ ) on the 7 th day and $37 \%$ on the 28th day after establishing the syndrome (TANG et al., 2020; THACHIL, 2020). Therefore, despite the risk of thrombocytopenia from the use of heparin and data regarding individuals with scores lower than 4 on the above scale, in addition to the benefits indicated by data from studies for severe cases of COVID-19, mild to moderate conditions may benefit from thromboembolism prevention, the anti-inflammatory activity of heparin and its possib- le effects on the viral binding domains (THACHIL, 2020). As a consequence, the use of heparin, particularly enoxaparin and biosimilars, has been recommended by among Chinese specialists, the Italian Medicines Agency, and by the WHO in the official clinical management guide for COVID-19 - including as a preventive use in non-serious cases (WORLD HEALTH ORGANIZATION, 2020a).

\section{Concluding Remarks}

The pandemic caused by SARS-CoV-2 has led to the use of several medications for the treatment and even prevention of infection, although many of them have not been sufficiently evaluated regarding the efficacy and safety of administration for such purposes. With these uncertainties, the number of diver- 
ISSN: $2763-5724$

Vol. 01 - n 04 - ano 2021

Editora Acadêmica Periodicojs

gent opinions grows with whi- about anticoagulation? Anales

ch therapeutic tactics should be used in COVID-19. Therefore, an approach must be carried out using protocols that differentiate the phase in which viral pathogenicity is dominant versus when the host's inflammatory response overcomes the pathology, so that the use of different drugs obtains viable potential effects. Given the multiplicity of treatment protocols adopted by each health care institution, as well as the large number of articles published so far, studies that seek to gather the data published so far on anti-inflammatory and anticoagulant drugs used for the treatment of COVID- 19 are important for a better therapeutic decision. del Sistema Sanitario de Navarra, [s. 1.], 2020. Available at: https:// doi.org/10.23938/ASSN.0884

ANVISA. Bulário Eletrônico. [S. 1.], 2007. Available at: http:// www.anvisa.gov.br/datavisa/fila bula/index.asp.

BEZERRA, C. M. Diagnóstico molecular da talassemia a+ (deleção -a3.7) em indivíduos com microcitose e/ou hipocromia atendidos no Hemocentro Dalton Barbosa Cunha em Natal, Rio Grande do Norte. Revista Brasileira de Hematologia e Hemoterapia, [s. 1.], v. 32, n. 1, p. 90-91, 2010. Available at: https://doi.org/10.1590/S151684842010000100022

\section{References:}

BUSHRA, R.; ASLAM, N. An ÁLVAREZ-RODRÍGUEZ, E. Overview of Clinical PharmacoLearning with COVID-19: what logy of Ibuprofen. Oman Medi-

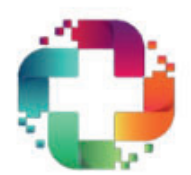


Vol. 01 - n 04 - ano 2021

Editora Acadêmica Periodicojs

cal Journal, [s. 1.], v. 25, n. 3, p. 155-161, 2010. Available at: https://doi.org/10.5001/omj.2010.49

CLAUSEN, T. M. et al. SARS-CoV-2 Infection Depends on tps://oi.org/10.1136/bmj.m2648

Cellular Heparan Sulfate and ACE2. Cell, [s. 1.], v. 183, n. 4, p. 1043-1057.e15, 2020. Available at: https://doi.org/10.1016/j. cell.2020.09.033

JOHNSON, R. M.; VINETZ, J. M. Dexamethasone in the management of covid -19. BMJ, [s. 1.], p. m2648, 2020. Available at: ht-

LESTER, M.; SAHIN, A.; PASYAR, A. The use of dexamethasone in the treatment of $\mathrm{CO}$ VID-19. Annals of Medicine and Surgery, [s. 1.], v. 56, p. 218-219, DEXAMETHASONE IN HOS2020. Available at: https://doi.orPITALIZED PATIENTS WITH g/10.1016/j.amsu.2020.07.004 COVID-19. New England Journal of Medicine, [s. 1.], v. 384, n. 8, p. 693-704, 2021. Available at: https://doi.org/10.1056/NEJMoa2021436

LINGAMANENI, P. et al. Heparin-Induced Thrombocytopenia in COVID-19. Journal of Investigative Medicine High Impact Case Reports, [s. J, F.; P, B.; W, J. Advances in He1.], v. 8, p. 232470962094409 , parins and Related Research. An 2020. Available at: https://doi. Epilogue. Molecules, [s. 1.], v. 23, org/10.1177/2324709620944091 n. 2, p. 390 , 2018. Available at: https://doi.org/10.3390/molecules23020390

MICALLEF, J.; SOEIRO, T.; JONVILLE-BÉRA, A.-P. Non-s- 
ISSN: $2763-5724$

Vol. 01 - n 04 - ano 2021

Editora Acadêmica Periodicojs

teroidal anti-inflammatory drugs, pharmacology, and COVID-19 infection. Therapies, [s. 1.], v. 75, n. 4, p. 355-362, 2020. Available at: https://doi.org/10.1016/j.therap.2020.05.003

MINISTÉRIO DA SAÚDE. Diretrizes para diagnostico e tratamento da COVID-19 versão 1. [S. 1.], 2020a.

MINISTÉRIO DA SAÚDE. Guia de Vigilância Epidemiológica: emergência de saúde pública de importância nacional pela doença pelo coronavírus. [S. 1.], 2020b. Available at: http://www. saude.gov.br/svs\%0Ahttps://portalarquivos.saude.gov.br/images/ pdf/2020/April/07/GuiaDeVigiEpidemC19-v2.pdf.

MULLOY, B. et al. Pharmacology of Heparin and Related Drugs. Pharmacological Reviews, [s. 1.], v. 68 , n. 1, p. $76-141,2016$. Available at: https://doi.org/10.1124/

pr.115.011247

NATIONAL CENTER FOR BIOTECHNOLOGY INFORMATION. PubChem Compound Summary for CID 3672, Ibuprofen. [S. 1.], 2020a. Available at: https://pubchem.ncbi.nlm.nih. gov/compound/Ibuprofen.

NATIONAL CENTER FOR BIOTECHNOLOGY INFORMATION. PubChem Compound Summary for CID 5743, Dexamethasone. [S. 1.], 2020b. Available at: https://pubchem.ncbi.nlm. nih.gov/compound/Dexamethasone.

PAHO. Folha informativa COVID-19 - Escritório da OPAS e da OMS no Brasil - OPAS/OMS. [S. 1.], 2020. Available at: https:// www.paho.org/pt/covid19\#cloro- 
Vol. 01 - n 04 - ano 2021

Editora Acadêmica Periodicojs

quina.

1.], v. 177 , n. 21 , p. 4899-4920,

2020. Available at: https://doi.

PARZY, G. et al. Venous Throm-

org $/ 10.1111 / \mathrm{bph} .15206$

boembolism Events Following

Venovenous Extracorpore-

SIDDIQI, H. K.; MEHRA, M.

al Membrane Oxygenation

R. COVID-19 illness in native

for Severe Acute Respiratory

and immunosuppressed states: A

Syndrome Coronavirus $2 \mathrm{Ba}-$

clinical-therapeutic staging pro-

sed on CT Scans. Critical Care

posal. The Journal of Heart and

Medicine, [s. 1.], v. 48, n. 10,

Lung Transplantation, [s. 1.], v.

p. e971-e975, 2020. Availab-

39 , n. 5, p. 405-407, 2020. Avai-

le at: https://doi.org/10.1097/

lable at: https://doi.org/10.1016/j.

CCM.0000000000004504

healun.2020.03.012

PATEL, S. K. et al. Dexame-

SMART, L. et al. A narrative thasone: A boon for critically ill review of the potential pharmaCOVID-19 patients? Travel Mecological influence and safety of dicine and Infectious Disease, [s. ibuprofen on coronavirus disease 1.], v. 37 , p. 101844,2020 . Avai19 (COVID-19), ACE2, and the lable at: https://doi.org/10.1016/j. immune system: a dichotomy of tmaid.2020.101844 expectation and reality. Inflammopharmacology, [s. 1.], v. 28, n.

ROBB, C. T. et al. Non-steroidal 5, p. 1141-1152, 2020. Available anti-inflammatory drugs, prosat: https://doi.org/10.1007/s10787taglandins, and COVID-19. Bri020-00745-z tish Journal of Pharmacology, [s. 
SPOORENBERG, S. M. C. et al. 2020. Available at: https://doi.

Pharmacokinetics of oral vs . in- org/10.1111/jth.14817

travenous dexamethasone in patients hospitalized with commuTHACHIL, J. The versatile henity-acquired pneumonia. British parin in COVID-19. Journal of Journal of Clinical PharmacoThrombosis and Haemostasis, logy, [s. 1.], v. 78, n. 1, p. 78-83, [s. 1.], v. 18, n. 5, p. 1020-1022, 2014. Available at: https://doi. 2020. Available at: https://doi. org/10.1111/bcp.12295 org/10.1111/jth.14821

STERnE, J. A. C. et al. Association Between Administration of Systemic Corticosteroids and Mortality Among Critically Ill Patients With COVID-19. JAMA, [s. 1.], v. 324, n. 13, p. 1330, 2020. Available at: https:// doi.org/10.1001/jama.2020.17023

TANG, N. et al. Anticoagulant treatment is associated with decreased mortality in severe coronavirus disease 2019 patients with coagulopathy. Journal of Thrombosis and Haemostasis, [s. 1.], v. 18, n. 5, p. 1094-1099,
THEOHARIDES, T. C.; CONTI, P. Dexamethasone for COVID-19? Not so fast. Journal of biological regulators and homeostatic agents, [s. 1.], v. 34, n. 3, p. 1241-1243, [s. d.]. Available at: https://doi.org/10.23812/20-EDITORIAL $1-5$

TOVAR, A. M. F. et al. Structural and haemostatic features of pharmaceutical heparins from different animal sources: challenges to define thresholds separating distinct drugs. Scientific Reports, [s. 1.], v. 6, n. 1, p. 35619,

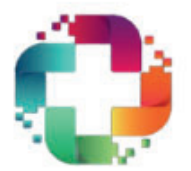


Vol. 01 - n 04 - ano 2021

Editora Acadêmica Periodicojs

2016. Available at: https://doi. org/10.1038/srep35619

TRINDADE, G. G. et al. COVID-19: therapeutic approaches description and discussion. Anais da Academia Brasileira de Ciências, [s. 1.], v. 92, n. 2, 2020. Available at: https://doi.org/10.1590/00013765202020200466

UNIVERSITY, J. H. COVID-19

Dashboard. [S. 1.], 2021. Available at: https://coronavirus.jhu.edu/ map.html.

WORLD HEALTH ORGANIZATION. Clinical management of COVID-19. [S. 1.], 2020a. Available at: https://www.who. int/publications/i/item/clinical-management-of-covid-19.

WORLD HEALTH ORGANIZATION. Coronavirus disea- se (COVID-19). [S. 1.], 2020b.

Available at: ttps://www.who.

int/emergencies/diseases/novel-coronavirus-2019/question-and-answers-hub/q-a-detail/coronavirus-disease-covid-19. 